\title{
Acute encephalopathy associated with severe fever with thrombocytopaenia syndrome
}

\author{
Manami Fujita, Yasuhiro Nakano, Hiroyuki Honda, Hideharu Hagiya
}

Department of General Medicine, Okayama University Graduate School of Medicine Dentistry and Pharmaceutical Sciences, Okayama, Japan

\section{Correspondence to}

Dr Hideharu Hagiya; hagiya@okayama-u.ac.jp

Accepted 19 November 2020

\section{DESCRIPTION}

In July 2020, a 72-year-old Japanese woman with hypertension and dyslipidaemia presented with a 5 -day history of fatigue and anorexia, followed by fever, slurred speech and involuntary movement of the upper limbs. She had not travelled abroad recently. She lived at the edge of a copse located in Okayama, a western prefecture of Japan and worked in the fields every day. On examination, she was disoriented (Glasgow Coma Scale, E4V3M6) and presented with postural tremor as well as myoclonus of the upper extremities (video 1) with blepharoclonus (video 2). Physical investigation did not detect any skin rashes or eschars. Her blood test results revealed the following: white cell count, $2790 / \mu \mathrm{L}$ (normal: 3300-8600); atypical lymphocytes, $17.3 \%$; platelet, $7.4 \times 10^{4} / \mu \mathrm{L}(15.8$ $\left.34.8 \times 10^{4}\right)$; aspartate aminotransferase, $128 \mathrm{U} / \mathrm{L}$ (13-30); creatine kinase, $1404 \mathrm{U} / \mathrm{L}$ (41-153); ferritin, $3810 \mathrm{ng} / \mathrm{mL}(6.2-138.0)$ and $\mathrm{C}$ reactive protein, $0.23 \mathrm{mg} / \mathrm{dL}(<0.15)$. The clinical course was suspicious of severe fever with thrombocytopaenia syndrome (SFTS). Her serum sample was sent for a PCR test for SFTS virus (SFTSV), which tested positive. Although MRI of the head was unremarkable, and cerebrospinal fluid examination showed only mildly elevated protein $(87 \mathrm{mg} / \mathrm{dL}$,

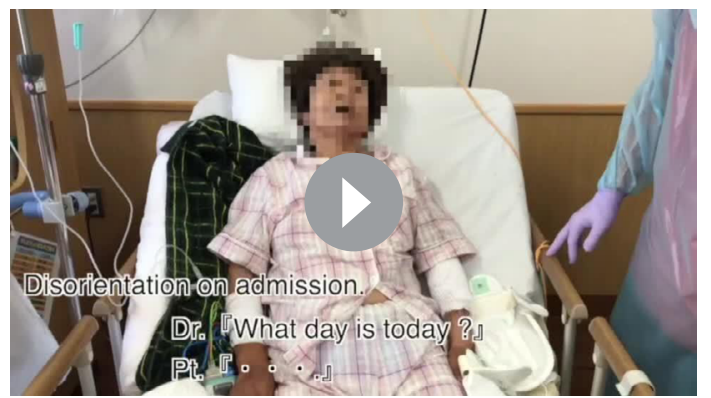

Video 1 Disorientation, myoclonus of the upper extremities and postural tremor on admission

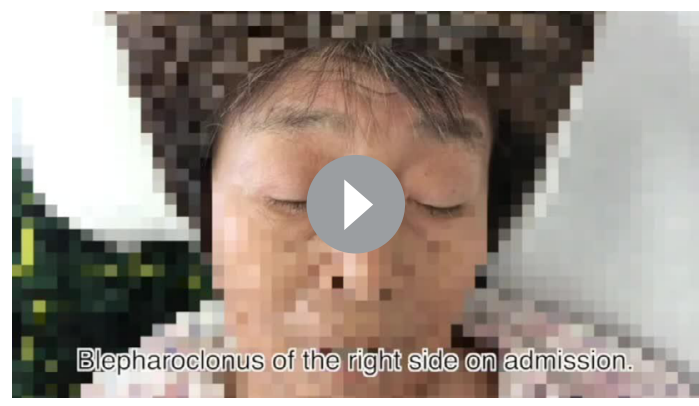

Video 2 Blepharoclonus of the right side on admission normal: $10-40)$ with normal cell counts $(2 / \mu \mathrm{L})$, electroencephalography revealed the presence of theta waves, indicating acute encephalopathy associated with SFTS. She was treated with high-dose methylprednisolone therapy $(1000 \mathrm{mg} /$ day for 3 days $)$ for neurological complications. The next day, her neurological symptoms had improved markedly, and the slurred oral communication and involuntary eye movement ameliorated within a few days. She was discharged on the 13th hospitalisation day with only a mild residual tremor (video 3).

SFTS, a potentially fatal tickborne disease caused by SFTSV, is endemic to East Asia, including China, South Korea, Japan, Taiwan and Vietnam. SFTS can potentially cause multiple organ complications and has a mortality rate of $30 \%$. Neurological complications are relatively common (71\%) in Japanese patients with SFTS, ${ }^{1}$ the symptoms of which include disorientation, muscle weakness, tremor, dysarthria and seizures lasting between 5 days and 2 weeks. ${ }^{2}$ Imaging studies using CT and MRI usually show no abnormalities in the head, while mild abnormalities in protein, glucose and cell count can be observed during cerebrospinal fluid examination. ${ }^{34}$ Elevated levels of cytokines, such as interleukin- 8 and monocyte chemoattractant protein-1, have been reported in the spinal fluid of patients, suggesting that SFTSV-associated cytokine storm may contribute to the development of encephalopathy. ${ }^{5}$ Although glucocorticoid may be commonly administered for virus-associated encephalopathy with the expectation of inhibiting cytokine production and function, ${ }^{6}$ its effectiveness is yet to be established; some literatures reporting effectiveness of the steroid therapy in acute encephalopathy ${ }^{78}$ and others not. ${ }^{9}$ While it has been reported that patients treated with glucocorticoid recovered without neurological sequelae,${ }^{34}$ the neurological impairment remained in the present case. Since neurological complications are poor prognostic factors for the quality

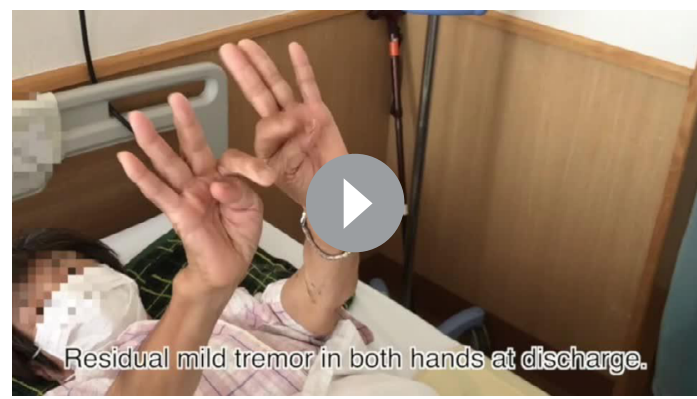

Video 3 Residual mild tremor in both hands at discharge 
of the remainder of the patient's life, the neurological findings should be noted in patients with SFTS.

\section{Patient's perspective}

I do not remember the week around the time of my admission to the hospital. I have trouble writing now because my hands are still shaky.

\section{Learning points}

- A patient with severe fever with thrombocytopaenia syndrome (SFTS) can develop acute encephalopathy, thereby leading to various neurological manifestations.

- SFTS can leave neurological sequelae, and follow-up should be performed after recovery.

Contributors MF, YN, HHo and HHa have all contributed to the patient's management and drafting of the manuscript.

Funding The authors have not declared a specific grant for this research from any funding agency in the public, commercial or not-for-profit sectors.

Competing interests None declared.

Patient consent for publication Obtained.
Provenance and peer review Not commissioned; externally peer reviewed.

\section{ORCID iD}

Hideharu Hagiya http://orcid.org/0000-0002-5086-1891

\section{REFERENCES}

1 Kato $\mathrm{H}$, Yamagishi T, Shimada T, et al. Epidemiological and clinical features of severe fever with thrombocytopenia syndrome in Japan, 2013-2014. PLoS One 2016;11:e0165207.

2 Gai Z-T, Zhang Y, Liang M-F, et al. Clinical progress and risk factors for death in severe fever with thrombocytopenia syndrome patients. J Infect Dis 2012;206:1095-102.

3 Nakamura S, Azuma M, Maruhashi T, et al. Steroid pulse therapy in patients with encephalopathy associated with severe fever with thrombocytopenia syndrome. J Infect Chemother 2018;24:389-92.

4 Kawaguchi T, Matsuda M, Takajo I, et al. Severe fever with thrombocytopenia syndrome with myocardial dysfunction and encephalopathy: a case report. J Infect Chemother 2016;22:633-7.

5 Park SY, Kwon J-S, Kim JY, et al. Severe fever with thrombocytopenia syndromeassociated encephalopathy/encephalitis. Clin Microbiol Infect 2018;24:432.e1-432.e4.

6 Stahn C, Buttgereit F. Genomic and nongenomic effects of glucocorticoids. Nat Clin Pract Rheumatol 2008;4:525-33.

7 Kimura E, Goto H, Migita A, et al. An adult norovirus-related encephalitis/ encephalopathy with mild clinical manifestation. BMJ Case Rep 2010. doi:10.1136/ bcr.03.2010.2784

8 Okumura A, Mizuguchi M, Kidokoro H, et al. Outcome of acute necrotizing encephalopathy in relation to treatment with corticosteroids and gammaglobulin. Brain Dev 2009;31:221-7.

9 Hatachi T, Michihata N, Takeuchi M, et al. Early steroid pulse therapy among children with influenza virus-associated encephalopathy. J intensive care 2020;8:62.

Copyright 2020 BMJ Publishing Group. All rights reserved. For permission to reuse any of this content visit

https://www.bmj.com/company/products-services/rights-and-licensing/permissions/

BMJ Case Report Fellows may re-use this article for personal use and teaching without any further permission.

Become a Fellow of BMJ Case Reports today and you can:

- Submit as many cases as you like

- Enjoy fast sympathetic peer review and rapid publication of accepted articles

- Access all the published articles

- Re-use any of the published material for personal use and teaching without further permission

Customer Service

If you have any further queries about your subscription, please contact our customer services team on +44 (0) 2071111105 or via email at support@bmj.com.

Visit casereports.bmj.com for more articles like this and to become a Fellow 